\title{
Spiritual Health and the COVID-19 Pandemic: Impacts on Orthodox Christianity Devotion Practices, Rituals, and Religious Pilgrimages
}

\section{Andreas S. Papazoglou, et al. [full author details at the end of the article]}

Accepted: 8 July 2021 / Published online: 14 July 2021

(C) The Author(s), under exclusive licence to Springer Science+Business Media, LLC, part of Springer Nature 2021

\section{Abstract}

The impact of the COVID-19 pandemic on multiple aspects of physical and social health, including spiritual and religious dimensions, has been discussed not only by numerous theologians, scientists, and politicians, but also by millions of believers of all faiths worldwide. The pandemic seems to have exerted a significant impact on religious practices. Massive gatherings of devoted and faithful people have been strongly discouraged and even openly banned. Prominent religious festivals and pilgrimages that have been conflated by the media with other "mega-spreader events" are incessantly canceled to mitigate the pandemic and alleviate the burden of COVID-19 on the healthcare system. The impact of the pandemic on Catholic or Muslim religious tourism has been extensively described in peer-reviewed and gray literature. However, observant members of the Orthodox Christianity faith have also experienced the constrictive prohibitions for gathering at and worshiping in shrines, churches, and monasteries. Among the manifestations of devotion that the pandemic has interfered with are the attendance to public worship spaces for the celebration of rites and ceremonies, like the celebration of Orthodox Easter. Expressions of reverent devotion including the kissing of crosses and icons as well as the sacrament of Holy Communion may have also been considered a motive of concern as these holy objects and the spoon used might act as fomites in the dissemination of the virus. Visitation of holy places has been also hampered by the pandemic. The most important centers of pilgrimage for Orthodox Christianity are Mount Athos and Jerusalem, as well as the Shrine of Panagia Evangelistria in the Island of Tinos, Greece. Authorities have halted almost completely the arrival of visitors to these sites. This paper aims at elaborating on the impact that the COVID-19 pandemic has had on social manifestations of religiosity and therefore taking a toll on the spiritual health of believers who have deeply rooted religious convictions and are strongly attached to Church tradition. This analysis closes with the provision of specific suggestions for the care, support, and healing of the impacted or splintered spiritual health of the believers who cannot participate in expressions of devotion, such as pilgrimages and religious tourism because of personal and public health concern, such as the COVID-19 pandemic. 
Keywords COVID-19 $\cdot$ Spiritual health · Orthodox Christianity $\cdot$ Pilgrimages

\section{Background}

Although there is limited agreement on the significance of the term "spiritual health," it may be fathomed in documents that describe health as an all-encompassing, complete experience. For example, the definition of the World Health Organization that describes health as being "a state of complete physical, mental and social well-being and not merely the absence of disease or infirmity" gives enough room to contain spirituality as an indivisible element of mental/emotional and social wellness that may impact the physical dimension as well. Yet, a comprehensive vision of health cannot incorporate spiritual health by merely relegating it to the living of inner experiences and beliefs, but it must include in a very prominent manner the wellness derived from being part of the public dimensions of any organized creed or religion.

Coronavirus disease-2019 pandemic (known as COVID-19 and caused by SARSCOV-2) has already evolved into an international lifestyle regulator exerting great influence on spirituality and religious practices as well (Kowalczyk et al., 2020; Papadopoulos et al., 2021). Globally, the most prominent religious events have had to be canceled, postponed, or substantially scaled-down, resulting in the substantial decrease in church attendance, participation in festivities considered holy in nature, and decline in religious tourism. The pandemic is undoubtedly taking an equalitarian toll since it seems to figuratively be abiding to the religious tolerance proclamation of the Edict of Milan. This is because the scourge is affecting a very ample gamut of faithful of multiple religions and not exclusively some of them (Baker et al., 2020). Governments from all around the world have reacted to the pandemic with urgent preventive restrictions and preparedness measures to avert the spreading of a highly transmissible air-borne virus. The measures undertaken have been directed at precluding agglomerations of large crowds by canceling or postponing religious festivals, such as Easter, Ramadan, Makara Jyothi, Bishwa Ijtema, and Black Nazarene, as well as pilgrimages, including Mount Athos, Hajj, and Umrah (Aggrawal et al., 2020; Budaev, 2021; Ebrahim \& Memish, 2020; Khan et al., 2020; Mubarak \& Zin, 2020; Osei-Tutu et al., 2021; Pavli et al., 2020). We should acknowledge that these measures may have saved the world from aggravated circumstances and superspreader events, which could possibly have led to a spike in COVID-19 cases or mortality rates.

However, the impact of the COVID-19 pandemic on the religious life and spiritual health of millions of adherents is noteworthy and the policies implemented by governments as an attempt to mitigate the risk of COVID-19 transmission deserve further discussion. Mróz et al. have recently studied the impact of COVID-19 on pilgrimages and religious tourism in Europe during the pandemic after analyzing data from the largest Catholic shrines. They concluded that Catholic pilgrimage tourism decreased by $90-95 \%$ during the first six months of the pandemic, with significant reduction of elderly pilgrims (Mróz, 2021). 


\section{Constraints on Orthodox Religious Services and Easter Celebration Resulting from the Pandemic}

Orthodox Christianity constitutes the principal religious faith in both Greece (95\%) and Eastern Europe, with more than 300 million adherents globally (Ecumenical Patriarchate, 2013). In Greece, the authorities started imposing restrictions to religious services since March 2020. Although church leaders have come to terms with the authorities for the sake of public health, there have been conflicts scaling up during major religious celebrations (Grigoriadis, 2020). Yet, some rituals and devotion practices that might represent a risk of transmission are still common. Kissing of sacred objects (crosses, icons) and relics never ceased and neither the practice of using one single spoon to distribute Communion to all the faithful. Becatoros and Kantouris state that "The priest dips a spoon into the chalice of bread and wine ... and puts it into the mouth of the first person in line. Then, with a move that would alarm an epidemiologist, he dips the spoon back into the chalice and then into the next person's mouth. Again, and again, through the entire congregation..." and yet the Church affirms that no diseases have been transmitted through Communion in centuries of existence of the institution (Kantouris, E, Becatoros, 2020; Pellerin \& Edmond, 2013). The Holy Synod, the church's governing body, claims that any suggestion that illness or disease could be transmitted by Holy Communion is blasphemy, a stance echoed by the Church of Cyprus.

Even if the faithful keep prudent distance in the line for getting the Communion, the spoon used to distribute the bread soaked in wine they still share one single Communion spoon. Theologians argue that this practice does not entail any risk because the content of the chalice has changed its substance, a belief that is one of the pillars of Catholic and Orthodox Christians. Nevertheless, epidemiologists and public health experts sustain that infectious diseases, particularly those transmitted through saliva droplets and nasal secretions can be transmitted through contaminated objects regardless of their composition and symbolic nature. This situation entails a trilemma in which the public health expert wants (a) to avert new infections, (b) to give the best care to the spiritual health of the community, and (c) to demonstrate their highest respect and considerations to religious institutions, namely the Orthodox Christian Church.

With regard to Easter, the most important Orthodox celebration, it has been celebrated with significant restrictions in both 2020 and 2021. In 2020, all services were held without faithful attending, with an exception for clergy and assistive personnel (Editing Team GTP, 2020). In 2021 Easter was celebrated with congregations limited in size to ensure "social distancing," according to the shrines' capacity. All ceremonies were restricted to the interior or the external spaces of the churches, and religious parades were prohibited (Associated Press, 2021). The legitimacy that restrictions impose on religious freedom has been questioned, and although it has been justified by means of a public health emergency, the extent to which the emergency status can justify the limitations is still debated (Androutsopoulos, 2021). Both the restrictions and the heavy criticism 
on religious practices by popular and social media have posed a significant psychosocial burden on the believers (Demetri \& Eyerman, 2020). Many worshipers felt that major ceremonies, including the receipt of the Holy Fire from the sacred Tomb in Jerusalem, were undermined, while secular leaders and tourists would enjoy a hearty welcome despite the situation (Kampouris, 2021). Although the impact of this situation on the spiritual health of Greek Orthodox Christian congregations and individual faithful has not been thoroughly assessed yet, scholars have pointed out the possibility of this resulting in cultural trauma (also known as collective traumatic experience with possible negative impact in the future) (Demertzis \& Eyerman, 2020).

\section{The Burden of the Pandemic on Devotional Pilgrimages}

The above-mentioned restrictions may have also greatly affected Orthodox pilgrimage, a pivotal aspect of Orthodox spiritual life (Terzidou et al., 2017), within and outside Greece. However, evidence about the magnitude of the variations in Orthodox pilgrimages in the era of COVID-19 is still limited (Pavli et al., 2020). Hence, one purpose of this review, in addition to analyze the impact of the pandemic on Christian Orthodox religiousness, is to provide some general information about pilgrimage and pious tourism, as being experienced in Greece following the proscriptions to visit Mount Athos, the Shrine of Panagia Evangelistria in Tinos and the Holy Places in Jerusalem.

\section{Religious Tourism to and Sojourn at Mount Athos}

Mount Athos, commonly known as the Holy Mountain (Agion Oros) or the Garden of the Virgin Mary, is located in a peninsula in Halkidiki, Greece. Mount Athos is deemed as the spiritual capital of the Orthodox Christian world since 1054. Mount Athos consists of 20 monasteries and about 700 dwellings, cells, or hermitages housing approximately more than 2000 Christian Orthodox monks from all over the world and hosting approximately 1000 male pilgrims every day (i.e., prior to the COVID-19 pandemic) coming from Greece and many other, predominantly EasternEuropean, countries. This venerated male-only destination has been recognized as an artistic site, included in the World Heritage List of UNESCO since 1988.

The momentousness of the Christian Orthodox belief in Greece and other countries, mostly within Eastern Europe, as well as the influential role of Mount Athos in their everyday life, is reflected upon the hundreds of thousands of pilgrims visiting Mount Athos annually (Paganopoulos, 2020). For a male pilgrim to visit Mount Athos a written permit (diamonitirion) from the "Holy Executive of the Holy Mount Athos" is required. Unfortunately, the number of Athos pilgrims had to be radically truncated during the last year (2020), as the Holy Mountain was not spared from the effects and the restrictions of the COVID-19 pandemic.

As a matter of fact, the first outbreak at Mount Athos occurred in March 2020, when four monks tested positive after traveling to Britain. Yet, they recovered 
quickly and without serious complications. The whole country-with Holy Mountain included-has been subject to several lockdowns since then, with the first quarantine (between March and May 2020) inflicting a hard blow to the Church by completely wrecking its Easter celebrations. Church leaders agreed to halt masses, and the only-male monastic community of Mount Athos reopened its doors to a restricted number of pilgrims in June 2020, provided they were in possession of the special permits required for visiting and lodging. To play on the safe side, all pilgrims and employees of the monasteries of the Athonite State were screened with a SARS-COV-2 PCR test, and the number of visitors was limited to 15 people per each one of the monasteries.

Nevertheless, Mount Athos has banned any visitors since November 2020, following the detection of at least eight COVID-19 cases at the monastery of Agios Pavlos (St. Paul). The autonomous state of Mount Athos has announced that it would not further accept any pilgrims as an attempt to curb the tide of the global outbreak of COVID-19 (Ekathimerini, 2020). Despite being under the direct jurisdiction of the Ecumenical Patriarch of Constantinople, the community, known for its austere rules, took this restrictive decision following a recommendation by the Greek government. The rationale behind this pilgrimage ban was to restrict public gatherings and the possibility of outsiders carrying into and transmitting the virus to the monastic community.

Greece has, at present time (May 2021), declared and is strictly observing a nationwide COVID-19 lockdown, and yet the death toll of the pandemic keeps increasing, with more than 6 thousand COVID-related cumulative fatalities registered as of March of 2021 (M. Roser, 2020). The implementation of stringent public health infectious disease control measures and the availability of medical resources and supplies within the monastic community may certainly have been crucial for permitting the uninterrupted observance of the liturgy and conduction of religious rituals by the permanent residents of the peninsula. However, the imposed restrictions have negatively affected the region, particularly because the number of visitors was extremely diminished in comparison with the around 250 thousand visitors who reached this destination during 2019 (Ekathimerini, 2019). It is worth noting that in contemporary times, such a radical and immense upheaval due to any other epidemic has not been recorded in Mount Athos (Mróz, 2021).

More recently, the "Holy Executive of the Holy Mount Athos" has made every effort to ensure more pilgrimage permits are issued. Nonetheless, the government has been adamant and has not altered the decisions taken on this issue in view of the onset of COVID-19 outbreaks associated with the spreading of new viral variants. A great number of monks and thousands of Orthodox believers call for moderation in the measures and leniency in their observance to give enough room for religious practices, while the Greek Government announced that a safe return to "pilgrimage normality" would be granted only after achieving a massive vaccination of Greek citizens. It must be mentioned that Greece is on the top five European countries in the attainment of benchmarks of vaccination. In fact, its immunization system, campaigns, distribution, and actual inoculations are recognized as one of the most wellorganized and executed across the European Union. 


\section{Pilgrimages to the Shrine of Panagia of Tinos}

Given that massive gatherings of pilgrims in a closed worship precinct may serve as unique occasions for the spreading of infectious diseases, particularly air-borne ones such as COVID-19, every Greek shrine was closed during the first lockdown (from March till May 2020). Similar restrictive measures have been imposed and implemented by the Greek government afterward.

The icon of Panagia Evangelistria is the most notorious and regarded as extremely miraculous icon throughout Greece. It is also the most venerated item in the country, and it attracts huge crowds of devout pilgrims to its Shrine, the Church of Annunciation (Evangelistria) in Tinos. Though a small island of Northern Cyclades, Tinos attracts thousands of visitors annually who are eager to behold, venerate, and pray to the charismatic icon. Some may ask for some type of cure and restoration of well-being since it is also believed the icon has health-giving and healthrestoring faculties (Foskolos, 2005). In 2016, Tinos Port Authority recorded 225,000 tourist arrivals to the island over the summer months (Tinos Port Authority, 2017). Every year on August 15 on the Greek Orthodox Christian calendar, the Feast of the Dormition of the Theotokos (Virgin Mary) is grandiosely celebrated with thousands of visitors arriving to the Church of Annunciation in Tinos. However, on August 15, 2020, only a restricted number of pilgrims were permitted to enter the church for the celebration. In fact, the total number of visitors of Tinos decreased by $90-95 \%$ during the COVID-19 pandemic. Moreover, the negative effects that the COVID-19 pandemic had on the religious tourism industry of the island, wreaked havoc among the local community that greatly depends on the religious tourism for its subsistence.

\section{Pilgrimage to the Holy Places in Jerusalem}

The Covid-19 pandemic could not leave the Holy Land untouched. This area, which is located between the Jordan River and the Mediterranean Sea, is deemed as one of the most important pilgrimage centers, not only for Christians and Jews, but also for Muslims. The term "Holy Land" (or "Holy Places") usually refers to areas within the modern State of Israel, the Palestinian territories, Western Jordan, and sectors in both Southern Lebanon and in South-Western Syria. In this section, we will discuss mainly the impact of the pandemic on the religious pilgrimage to Jerusalem, in which the Church of the Holy Sepulcher (within which the tomb of Jesus Christ millenary tradition affirms to be located) is found and that it is almost certainly the most popular site of pilgrimage to the Holy Land for Orthodox and Catholic Christians.

In February 2020, the state of Israel took measures to reduce the spread of COVID-19. This was the first month in which traveling in Israel became subject to limitations such as obligatory quarantine upon arrival. At the same time in Greece, on March 3, 2020, two of the first COVID-19 cases were notified to the National Public Health Organization of Greece among pilgrims returning from Jerusalem on February 27, 2020, with a direct flight from Tel Aviv, Israel (Pavli et al., 2020). Both pilgrims were symptomatic during the flight. These two patients were part of a large 
group of 53 pilgrims visiting Jerusalem on February 19, 2020. Their trip included visits to the Holy Land, transportation in buses and residing in the same hotels.

From March 2020 and onward, a lockdown was imposed in Israel, while homebased work was promoted, and the use of masks was rendered mandatory. Gatherings of more than 10 people were also banned, and therefore, pilgrimage tourism and all religious services were postponed. During the spring of 2020, numerous citizens highlighted the need for proportional and equitable enforcement of measures among various religious, faith-based, and cultural communities, as several significant religious celebrations were canceled, including the Hebrew Passover and the Christian Easter. The government of Israel enforced a massive vaccination program from December 2020 and, nowadays (May 2021), has achieved one of the greatest vaccination rates of vaccination worldwide. A recent study showed a significant reduction in the number of active cases among the vaccinated population (Mallapaty, 2021).

The Roman Catholic Church, namely the Franciscan Custodia Terrae Sanctae and the Latin Patriarch of Jerusalem, were the first among all Christian denominations to officially embrace the bans imposed by the State of Israel (Custodia, 2021a, 2021b; Latin Patriarchate of Jerusalem, 2021). Days later, the Armenian Patriarchate suspended its operation and closed its residence in St. James monastery, which is in the Armenian quarter of Jerusalem (Armenian Patriarchate of Jerusalem, 2021). Moreover, on March 26, 2020, an inter-religious prayer for the pandemic took place in Jerusalem, including Christians, Muslims, and Jews (Custodia, 2021a, 2021b). For making more flexible the hard governmental restrictions, Israel started opening to foreign citizens and pilgrims only in February. During most of the year, no more than 20 individuals had permission to simultaneously enter to and stay in a church, except on December 25 and January 7, when all Christian denominations were permitted to celebrate Christmas according to their calendar and with an allowance of up to 100 visitors outside each church and keep distance among worshipers.

Regarding the Church of the Holy Sepulcher, the pilgrimage was initially restricted in March 2020, but afterward visitors were completely banned. Consequently, rites such as the Ceremony of the lighting of the Holy Fire, which happens annually on the day (Holy Saturday), preceding the Orthodox Easter (Sunday) took place without attendance of pilgrims. Church representatives from all over the world, responsible to transmit the Holy Fire to their countries, had to wait in their planes in the Tel Aviv Ben Gurion Airport. The Church of the Holy Sepulcher was reopened on May 24, 2020, but less than 50 visitors could simultaneously remain inside (Jerusalem Patriarchate News, 2021). From September 2020 until February 2021 the government imposed stricter measures and allowed only five individuals to enter simultaneously. After achieving fast rates of massive vaccination, the state has allowed pilgrims and visitors inside the Church of the Holy Sepulcher from February 2021 and onward. It is important to mention that on Fridays and Sundays, the temple is only opened for the clergy. The other churches in the city are authorized to receive a maximum of 20 people inside.

The achievement of a high prevalence of Israeli citizens who have already received at least one dose of the Covid-19 vaccine has partly restored normality in everyday life in Israel. Israeli authorities have organized plans for vaccination 
certificates, which might allow vaccinated pilgrims from Greece and Cyprus to enter Israel and the Holy Land without having to self-quarantine, while this document may be a good way to ascertain who has been already inoculated and therefore less prone to transmit or contract the infection. This measure, however, can be a doubleedged sword because this "Green Passport" (or Yellow or White Passport) might be a tool for the creation of discriminatory policies toward the population groups whose vaccination is contraindicated, i.e., children, pregnant women, and other groups and communities (Corona Ramzor Site, 2021). Concerning religion and pilgrimage tourism, the first visible progress after the vaccination began was the progressive reopening of all temples, churches, and shrines in Israel, which have been registered in the green passport program. Thus, churches will be initially allowed to receive up to one person on every seven square meters. Of course, handling the post-COVID pilgrimage is expected to be controversial concerning the fact that restricted access to certain religious sites or practices can be associated with discrimination.

\section{Remaining Concerns, Study Limitations, Future Perspectives, and Recommendations in the Field of Spiritual Health}

Most scholars and experts would agree that spiritual health is more than the intrapersonal system of beliefs in values, principles, and ideologies that bring the individual closer to the essence of his/her faith. The total fulfillment of spiritual health also requires social expressions of admiration, devotion, sharing of convictions, and principles and/or worshiping in community. Religion is therefore an essential element for the development and expression of spiritual health. Although spiritual health has been poorly addressed, even by large health agencies, institutions, and organizations, it plays a critical role in the cultivation of emotional and mental wellness. It can even contribute to physical healing as many healthcare providers can attest it occurs when the patients receive spiritual support. Also, spiritual providers can attest that the full attainment of spiritual health may contribute to remove negative attitudes and behaviors within communities. Participation in religious ceremonies, rites, and pilgrimages may consolidate social bonds and the sense of belonging to a community which are essential for enjoying total health and well-being.

The pandemic may have caused, however, a sense of hopelessness, fear, and loss of faith. It might have also resulted in isolation, loss of emotional interactions, impossibility to show veneration for holy objects and to worship in holy sites (Kowalczyk et al., 2020). Every human being has an intrinsic need to find an optimal place for both introspectively and expressively manifesting his/her beliefs, convictions, and values. For a large amount of religious people, principal pilgrimage sites are located away from their households making travel a dire spiritual need. These religious wayfarers or pilgrims may still face further restrictions soon to travel to the revered places they wish to visit. International public health experts express concern about the possibility of infected returning pilgrims sparking new waves of infections in their communities or transmit a more virulent SARS-COV-2 strain. This might render a complete lift of the pilgrim ban hard to attain. This challenge becomes even more crucial, when considering, for example, the fact that foreign pilgrims 
constitute more than $25 \%$ of the total population visiting Greek pilgrimage sites (Terzidou et al., 2017). Yet, we are not able to clearly define in which stage of the pandemic we are currently at, and mass religious gatherings might still pose a critical public health risk in the context of the potential spread of SARS-COV-2 across the borders and within the communities. Without proper planning and preventative measures, religious pilgrimage festivals could lead to overburdened healthcare systems of the hosting countries and impact global health readiness.

Therefore, it is of great importance to sensitize the pilgrims on the need for personal protection and hygiene and improve compliance with preventative control measures (Monson et al., 2021). Voluntary postponement of the participation in religious rituals and festivals might be proposed for elderly pilgrims or for those with underlying comorbidities until the COVID-19 pandemic is under control. It is also critical for global public health and disease control that local communities hosting thousands of pilgrims annually should prepare an adequate quarantine infrastructure to minimize community transmission caused by returning pilgrims (Ebrahim \& Memish, 2020). Furthermore, many traditional pilgrimage and tourism facilities in churches and monasteries should be renovated, refurbished, or even reconstructed to guarantee future sanitary safety.

Finally, we should not discount the positive aspects related to pilgrimages and religious tourism during the pandemic. Online conferences and speeches with monks or abbots and other believers as participants were commonly held with great success in the era of COVID-19. For instance, the abbot of one of the largest monasteries of Mount Athos has been weekly catechizing, preaching, and answering to questions of thousands of orthodox believers from all over the world through online meetings accessible to everyone. Furthermore, the restrictions of pilgrimage during the pandemic and the thirst for spirituality, have led to an explosion in the production of documentaries and videos related to pilgrimage and religious sites. This high-quality electronic material has been watched and is expected to be watched by millions of people, increasing the desire of adherents to visit sacred places, and probably contributing to the increase of pilgrimage tourism after the COVID-19 pandemic. Recently, the abbot of Esfigmenou Monastery became the first Athonite to receive a Covid-19 vaccine. The monastic communities-either those residing in large monasteries or hermits-seem quite receptive to vaccination as a means of protecting the vulnerable elderly monks, maintaining daily spiritual gatherings in the church and, hopefully, welcoming visitors again soon (Romfea, 2021).

Addressing spiritual health in this context faces a number of intrinsic and extrinsic limitations. The lack of a globally acceptable definition of spiritual health and the differences between beliefs and practices between different Christian denomination and within the Orthodox Church in Greece and abroad act as inherent limitations. For instance, Catholic and Orthodox Christians receive the Holy Communion in different manners. Orthodox diaspora has been more open to alternative manners of receiving the Holy Communion than the Greek Orthodox Church. On top of this, this analysis focused on the Greek Orthodox Church and did not expand on the views and stance of the Orthodox Church in the Balkans, in the Eastern Europe and in Russia. Therefore, horizontal rules and guidelines can become equivocal. On the other hand, the legal status of the Orthodox Church in Greece and abroad 
(Israel) differs and this constitutes of a major external limitation toward analyzing the situation in equal terms and providing recommendations applying to the Orthodox Church worldwide. With regard to the methodology of this study, the authors extracted data from peer-reviewed or credible (highly recognized) press sources (where necessary), but did not conduct interviews or disseminate questionnaires to representatives of the clergy, the laity, the experts or the authorities.

Nonetheless, on the grounds of the presented evidence, some preliminary recommendations to address spiritual health amidst the COVID-19 pandemic would be:

1. To count on a reference document on spiritual health. For some other dimensions of health as whole (e.g., sexual health, reproductive health, adolescent health, etc.) many guides and tools have been developed, yet the field of spiritual health has been almost completely neglected. A consultation of experts in health promotion and care, theologians, church authorities, and representatives of faith-based organizations could gather to discuss a conceptual framework and to propose the guidelines and blueprints for reference documents to be developed by special commissions. The reference documents may adhere to already existing guides, such as the International Health Regulations, the WHO constitution, among others.

2. To explore the possibility of providing incentives to tourism-related industries and large or small businesses affected by the limitations imposed to pilgrimages, particularly to local business on the routes and in the sites of pilgrimage. Alternatives to presential pilgrimage might be further considered and implemented, such as videos and documentaries or even virtual reality experiences. The National Geographic Institute has made an exhibit to virtually visit the Holy Sepulcher that is astonishing. Similar options can be explored on other sites, after requesting Church authorities to inform the virtual travelers that the virtual visit has the validity of a real one.

3. In addition to TV and radio shows that broad cast religious services, programs and shows could be added on topics that might be interesting to people of all ages, with particular emphasis on seniors and on their beliefs and devotions. It would be interesting interviewing them and asking them to talk about their beliefs, convictions, and values.

\section{Conclusion}

The clear importance of controlling public health and preventing the transmission of infectious diseases at mass religious gatherings has been underlined by the COVID19 pandemic, which exposed the fragility and preparedness of healthcare systems around the globe. This study aimed to overview the experiences of measures practiced among great Christian Orthodox pilgrimages, including Mount Athos, Panagia of Tinos, and Jerusalem. Even if the pandemic caused a severe reduction in the number of pilgrims visiting these venerated destinations, proper palliative, alleviation, and preventive measures could foster a gradual return to the full enjoyment of their spiritual health, once the pandemic is curbed to resume pilgrimages. 


\section{Declarations}

Conflict of interest The authors declare that they have no conflict of interest.

\section{References}

Aggrawal, V., Dikid, T., Jain, S. K., Pandey, A., Khasnobis, P., Choudhary, S., Chandra, R., Patil, A., Maramraj, K. K., Talyan, A., Singh, A., Babu, B. S., Kumar, A., Kumar, D., Raveesh, P. M., Singh, J., Kumar, R., Qadri, S. S., Madan, P., \& Singh, S. K. (2020). Disease surveillance during a large religious mass gathering in India: The Prayagraj Kumbh 2019 experience. International Journal of Infectious Diseases, 101, 167-173. https://doi.org/10.1016/j.ijid.2020.09.1424

Androutsopoulos, G. (2021). The right of religious freedom in light of the coronavirus pandemic: The Greek case. Laws. https://doi.org/10.3390/laws10010014

Armenian Patriarchate of Jerusalem. (2021). Closed to visitors in order to contain spread of Coronavirus. Armenian-Patriarchate. https://armenian-patriarchate.com/old/closed-to-visitors-in-order-to-conta in-spread-of-coronavirus

Associated Press. (2021). Greece keeps lid on Orthodox Easter events as it eyes tourism season. www. euronews.com. https://www.euronews.com/2021/04/30/greece-keeps-lid-on-orthodox-easter-eventsas-it-eyes-tourism-season

Baker, J. O., Martí, G., Braunstein, R., Whitehead, A. L., \& Yukich, G. (2020). Religion in the age of social distancing: How COVID-19 presents new directions for research. Sociology of Religion, 81(4), 357-370. https://doi.org/10.1093/socrel/sraa039

Budaev, S. (2021). Safety and reverence: How Roman Catholic liturgy can respond to the COVID-19 pandemic. Journal of Religion and Health. https://doi.org/10.1007/s10943-021-01282-X

Corona Ramzor Site. (2021). What is a Vaccination Certificate? https://corona.health.gov.il/en/ green-pass/

Custodia, T. (2021). Covid-19: an inter-religious prayer in Jerusalem. https://www.custodia.org/en/news/ covid-19-inter-religious-prayer-jerusalem

Custodia, T. S. (2021). Letters to the Franciscan Friars of the Custody of the Holy Land. https://www. custodia.org/en/news/letters-franciscan-friars-custody-holy-land

Demertzis, N., \& Eyerman, R. (2020). Covid-19 as cultural trauma. American Journal of Cultural Sociology, 8(3), 428-450. https://doi.org/10.1057/s41290-020-00112-z

Ebrahim, S. H., \& Memish, Z. A. (2020). Saudi Arabia's drastic measures to curb the COVID-19 outbreak: Temporary suspension of the Umrah pilgrimage. Journal of Travel Medicinedoi. https://doi. org/10.1093/jtm/taaa029

Ecumenical Patriarchate. (2013) Theology. www.ec-patr.org/docdisplay.php?lang=grandcat=9\%3E

Editing Team GTP. (2020). Covid-19 Lockdown Keeps Greeks at Home for Easter. https://news.gtp.gr/ 2020/03/30/covid-19-lockdown-keeps-greeks-home-easter/

Ekathimerini. (2019). More than 250,000 pilgrims annually visiting Mount Athos. https://www.kathimerini.gr/society/1047546/perissoteroi-apo-250-000-proskynites-etisios-sto-agio-oros/

Ekathimerini. (2020). Mount Athos closes doors to pilgrims. https://www.ekathimerini.com/news/ 259106/mount-athos-closes-doors-to-pilgrims/

Foskolos, E. (2005). The panhellenic holy shrine of our lady of the annunciation of Tinos. http://users. hol.gr/lamp/panagia_eng

Grigoriadis, I. N. (2020). The Covid-19 Pandemic, Greece and the Ecumenical Patriarchate. http://seeso xdiaspora.org/publications/pandemic-blog/the-covid-19-pandemic,-greece-and-the-ecumenicalpatriarchate?fbclid=IwAR0BSWRd2OxGGs5r4HnNkjaVTxB3-TIzmzmc8zC6RN1keeMFhA18Sc 4I_Iw

Jerusalem Patriarchate News, G. (2021). Statement regarding the reopening of the Holy Sepulchre. https://en.jerusalem-patriarchate.info/blog/2020/05/23/statement-regarding-the-reopening-of-theholy-sepulchre/

Kampouris, N. (2021). Holy Light Arrives From Jerusalem to Athens to Mark Easter. https://greekrepor ter.com/2021/05/01/holy-light-arrives-from-jerusalem-to-athens-to-mark-easter/ 
Kantouris, E, Becatoros, A. (2020). Communion Unchanged in Greek Orthodox Church Despite Virus. https://www.usnews.com/news/world/articles/2020-05-29/communion-ritual-unchanged-in-ortho dox-church-despite-virus

Khan, A., Bieh, K. L., El-Ganainy, A., Ghallab, S., Assiri, A., \& Jokhdar, H. (2020). Estimating the COVID-19 risk during the Hajj pilgrimage. Journal of Travel Medicine. https://doi.org/10.1093/jtm/ taaa 157

Kowalczyk, O., Roszkowski, K., Montane, X., Pawliszak, W., Tylkowski, B., \& Bajek, A. (2020). Religion and faith perception in a pandemic of COVID-19. Journal of Religion and Health, 59(6), 2671-2677. https://doi.org/10.1007/s10943-020-01088-3

Latin Patriarchate of Jerusalem. (2021). Coronavirus in Israel: Latin Patriarchate urges to limit large gatherings. https://www.lpj.org/posts/coronavirus-in-israel-latin-patriarchate-urges-to-limit-large-gathe rings.html

M. Roser, et al. (2020). Coronavirus Pandemic (COVID-19). https://ourworldindata.org/covid-deaths

Mallapaty, S. (2021). Vaccines are curbing COVID: Data from Israel show drop in infections. Nature, 590(7845), 197-197. https://doi.org/10.1038/d41586-021-00316-4

Monson, K., Oluyinka, M., Negro, D., Hughes, N., Maydan, D., Iqbal, S., Golden, S. H., Teague, P., Hale, W. D., \& Galiatsatos, P. (2021). Congregational COVID-19 conversations: Utilization of medical-religious partnerships during the SARS-CoV-2 pandemic. Journal of Religion and Health. https://doi.org/10.1007/s10943-021-01290-X

Mróz, F. (2021). The impact of COVID-19 on pilgrimages and religious tourism in Europe during the first six months of the pandemic. Journal of Religion and Health. https://doi.org/10.1007/ s10943-021-01201-0

Mubarak, N., \& Zin, C. S. (2020). Religious tourism and mass religious gatherings — The potential link in the spread of COVID- Current perspective and future implications. Travel Medicine and Infectious Disease, 36, 101786. https://doi.org/10.1016/j.tmaid.2020.101786

Osei-Tutu, A., Affram, A. A., Mensah-Sarbah, C., Dzokoto, V. A., \& Adams, G. (2021). The impact of COVID-19 and religious restrictions on the well-being of Ghanaian Christians: The perspectives of religious leaders. Journal of Religion and Health. https://doi.org/10.1007/s10943-021-01285-8

Paganopoulos, M. (2020). Being and becoming a monk on mount athos: An ontological approach to relational monastic personhood in the "garden of the virgin Mary" as a rite of passage. Open Theology, 6(1), 66-87. https://doi.org/10.1515/opth-2020-0008

Papadopoulos, I., Lazzarino, R., Wright, S., Ellis Logan, P., \& Koulouglioti, C. (2021). Correction to: Spiritual support during COVID-19 in England: A scoping study of online sources. Journal of religion and health. https://doi.org/10.1007/s10943-021-01274-X

Pavli, A., Smeti, P., Papadima, K., Andreopoulou, A., Hadjianastasiou, S., Triantafillou, E., Vakali, A., Kefaloudi, C., Pervanidou, D., Gogos, C., \& Maltezou, H. C. (2020). A cluster of COVID-19 in pilgrims to Israel. Journal of Travel Medicine, 27(5), 1-3. https://doi.org/10.1093/jtm/taaa102

Romfea. (2021). First monks vaccinated at Mount Athos. https://www.romfea.gr/epikairotita-xronika/ 42490-emvoliastikan-oi-protoi-monaxoi-sto-agion-oros

Terzidou, M., Scarles, C., \& Saunders, M. N. K. (2017). Religiousness as tourist performances: A case study of Greek orthodox pilgrimage. Annals of Tourism Research, 66, 116-129. https://doi.org/10. 1016/j.annals.2017.06.009

Tinos Port Authority. (2017). Tinos island visitors. Tinos Port Authority Data.

Publisher's Note Springer Nature remains neutral with regard to jurisdictional claims in published maps and institutional affiliations. 


\section{Authors and Affiliations}

\section{Andreas S. Papazoglou ${ }^{1}$ (D) - Dimitrios V. Moysidis ${ }^{1} \cdot$ Christos Tsagkaris $^{2}$.} Marko Dorosh ${ }^{3} \cdot$ Efstratios Karagiannidis $^{1} \cdot$ Rafael Mazin $^{4}$

$\triangle$ Andreas S. Papazoglou

anpapazoglou@yahoo.com

1 First Department of Cardiology, AHEPA University Hospital, Aristotle University of Thessaloniki, St. Kiriakidi 1, 54636 Thessaloniki, Greece

2 Faculty of Medicine, University of Crete, Heraklion, Greece

3 Bukovinian State Medical University, Chernivtsi, Ukraine

4 Independent Consultant on Public Health and Sexual Health and Rights, Washington, USA 